\title{
Innovative vouchers and strategy of their introduction in the Volgograd region
}

\author{
Marina V. Ledeneva \\ Volzhskiy branch \\ Volgograd State University \\ Chair of Economic Theory and Management \\ Volzhskiy, Russia \\ mledenjova@yandex.ru
}

\author{
Maria V. Parfenova \\ Volzhskiy branch \\ Volgograd State University \\ Chair of Finance and Credit \\ Volzhskiy, Russia \\ pvv_65@mail.ru
}

\author{
Mikhail M. Guzev \\ Volzhskiy branch \\ Volgograd State University \\ Chair of Economic Theory and Management \\ Volzhskiy, Russia \\ guzev@vgi.volsu.ru
}

\begin{abstract}
The authors study the essence and the advantages of innovative vouchers and also they analyze the foreign experience of their application. The condition of the innovative entrepreneurship in the Volgograd region and the qualitative assessment of the efficiency of its encouragement are studied. The authors suggest the model and the strategy of the introduction of the innovative vouchers in the Volgograd region for the period of 2018-2023.
\end{abstract}

Keywords - innovation voucher, Volgograd region, small and medium sized entrepreneurship, innovative entrepreneurship, government encouragement of innovative acitivity

\section{INTRODUCTION}

The encouragement of the innovative activity and in particular of small and medium sized business is the priority of every state. The properties typical of small and medium sized enterprises (SMEs) - low level of expenses for organization and maintaining of business, flexibility, close interaction with consumers, quick reaction to the market demands, opportunity of producing small volumes of production, provision of specific services, willingness of having higher risks - make them an efficient object or a tool for the development and the introduction of progressive changes.

For the provision of the dynamic economic growth of Russia and its regions the transfer to the innovative type of economic development, the creation of the economy founded on the knowledge is indispensable. In the small and medium sized business (SME) where private interests prevail, the development and the introduction of innovations requires a specific motivation.

It is indispensable permanently to optimize and to improve the forms and ways of state support of small and medium sized businesses including the bench marketing allowing copying and adapting the foreign experience. One of the perspective tools for the encouragement of the small and medium sized innovative entrepreneurship in Russia is the innovative voucher which allows small and medium sized enterprises getting the servicing from scientific and research organizations within the limit (nominal volume) of the voucher.

The innovative voucher was invented in 1997 in Netherlands and soon having shown its efficiency spread to other European countries. It was introduced in the USA, Australia, Israel, Singapore and other nations. It presents a security (certificate) giving its owner (small and medium sized enterprise) the right of obtaining the scientific and research services from a university (institute), scientific research institute or a specialized consulting company within the nominal of the voucher for the solution of the problems of the enterprises.

The goal of the current research is the analysis of the opportunity for the introduction of innovative vouchers in the Volgograd region and the isolation of basic parameters of innovative voucher model. The tasks of the research are as follows: 1) finding the place for innovative vouchers within 
the tools of the state support of innovative small and medium sized business of the Volgograd region; 2) analysis of advantages, disadvantages and risks of use of innovative vouchers as the instrument of the encouragement of the innovative entrepreneurship in Russia at the federal and regional levels; 3) development of the mechanism of innovative vouchers use, their organizational basis; 4) making the plan of steps for the introduction of innovative vouchers in the Volgograd region.

\section{MATERIALS AND METHODS}

In the article the methods of abstract and logical approach, subject and object approach, comparative, level and statistical analyses were used.

The authors also studied the experience of foreign countries and of the Tomsk oblast (Tomsk region) in the introduction of innovative vouchers and also the relevant legal acts of the Russian Federation.

The tendencies and problems in the development of small and medium sized enterprises in the Volgograd region were shown on the basis of the statistical data of the Federal Service for State Statistics and its Volgograd subdivision.

When using the statistical data of the Federal Service for State Statistics in the Volgograd region, the reports of the Committee for Economic Policy and Development the authors carried out the quantitative assessment of the efficiency of measure of state support of small and medium sized enterprises and also of the state encouragement of the innovative activity of business according to the methodology developed and suggested by M.V. Parfenova in her thesis [1]. The amount of subsidies for small and medium sized business, number of vouchers issued by the non profit organization "Regional guarantee fund", amount of credits given by the state fund "Regional microfinance center" were studied as the tools of the state encouragement. The efficiency indices of the state support of small and medium sized enterprises of the government activity are as follows: number of small and medium sized enterprises, money turnover of small and medium sized businesses in current prices, number of the employed in SMEs. The efficiency indices of the innovative activity of enterprises are as follows: share of the organizations making technological innovations from the total number of organizations, shipped innovative products and advanced technologies in use.

By means of a comparative analysis of the tools partially dealing with innovative voucher the authors showed the place and the role of the innovative voucher within the support tools for innovative small and medium sized entrepreneurship which are already used.

The authors used the traditional approach to the development of the Strategy of the encouragement of small and medium sized enterprises in the Volgograd region with the help of innovative vouchers for years 2018-2023 (further Strategy) which include:

- $\quad$ specification of opportunities and threats;

- $\quad$ setting of goals and tasks of the Strategy;
- calculation of the required funds for the implementation of the Strategy;

- $\quad$ analysis of risks and development of measures for their minimization, development of the plan of measures scheduled for responsible persons;

- description of the mechanism and principles of the implementation of the strategy, control processes and the monitoring of its implementation.

\section{RESULTS AND DISCUSSION}

The experience of foreign countries shows that the main subjects in the model of the innovative voucher are:

- $\quad$ financial sponsor of the project;

- $\quad$ executive agency responsible for the coordination of the project;

- $\quad$ organizations providing scientific and research services mainly governmental ones;

- $\quad$ users of innovative vouchers which are small and medium sized enterprises as a rule.

The models of innovative vouchers vary according to the following basic criteria: period of use; amount of the innovative voucher (small innovation voucher lower than 5000 Euros; big innovation voucher higher than 5000 Euros under the condition of the co financing); criteria of selection of the companies for the participation in the contest; spheres of use of the innovative voucher; list of organizations providing services or its absence; region or country of functioning; assessment of innovative service suppliers; voucher application procedure; necessity of co financing of the services from the part of small and medium sized enterprises; order of payment (to the services supplier upon the presentation of the voucher or the reimbursement of the expenses of the small enterprise).

The innovation voucher allows encouraging the cooperation of small and medium sized enterprises with scientific and research organizations having the potential of the commercialization of R\&D and thank to that it contributes to the cooperation of the science and production.

In Russia in 2014-2015 the attempt of the introduction of innovative vouchers was taken by the Tomsk regional engineering center. The voucher could be given to the companies being part of the innovative territorial cluster "Pharmaceutics, medical equipment, information technologies of Tomsk cluster" which obtained support from federal budget. At first the planned mechanism of the innovative vouchers issuing meant its paper form and also the opportunity of choice by the users of the innovative vouchers of the companies which will help them. However in the Russian legislation the innovation voucher is not mentioned as a security. Meanwhile the Article 8 of the Federal law 44-FZ adopted April, 5" 2013 "About the contract system in the sphere of state purchases of goods, works and services for the provision of state and municipal» requires the selection of service providers on competitive basis. That's why the initial scheme was changed: innovative vouchers for small and 
medium sized enterprises were not issued in paper form. In order to avoid corruption the providers of services was carried out on the competitive basis.

It is indispensable to finance the issuing of innovative vouchers in the regions of Russia including the Volgograd region at the expense of regional budget before the corrections are made in the federal legislation of Russia dealing with legal nature of innovative vouchers. This type of financing is admissible in compliance with paragraph 3 of Article 16 of Federal Law № 209-FZ adopted July, 242007 "About the development of small and medium sized entrepreneurship in the Russian Federation".

In the Volgograd region the innovative entrepreneurship is more poorly developed than in the rest of Russia (Table 1). This situation is manifested by a smaller share of innovative goods and services in the total volume of the shipped goods, provided works and services in the Volgograd region in comparison with average levels in Russia and also is manifested by a lower share of organizations involved in innovations. But the index of the share of innovative products shows a certain tendency for growth. The share of organizations involved into innovations is reducing.

\section{TABLE I. DEVELOPMENT OF INNOVATIVE INTREPRENEURSHIP IN} VOLGOGRAD REGION IN 2010-2016

\begin{tabular}{|c|c|c|c|c|c|c|c|}
\hline Indices & 2010 & 2011 & 2012 & 2013 & 2014 & 2015 & 2016 \\
\hline $\begin{array}{c}\text { Share of innovative products, } \\
\text { works, services in total volume } \\
\text { of the shipped goods, } \\
\text { accomplished works, provided } \\
\text { services a } \\
\text { Russian Federation } \\
\text { Southern Federal District } \\
\text { Volgograd region }\end{array}$ & $\begin{array}{c}4,8 \\
6,5 \\
13,5\end{array}$ & $\begin{array}{l}6,3 \\
3,7 \\
5,2\end{array}$ & $\begin{array}{l}8,0 \\
3,0 \\
0,9\end{array}$ & $\begin{array}{l}9,2 \\
3,4 \\
1,1\end{array}$ & $\begin{array}{l}8,7 \\
4,8 \\
2,1\end{array}$ & $\begin{array}{l}8,4 \\
5,9 \\
2,5\end{array}$ & $\begin{array}{l}8,5 \\
8,4 \\
3,0\end{array}$ \\
\hline $\begin{array}{c}\text { Innovative activity of } \\
\text { organizations (share of } \\
\text { organizations making } \\
\text { technological, organizational, } \\
\text { marketing innovations in the } \\
\text { given year in the total number } \\
\text { of the analyzed organizations), } \\
\% \\
\text { Russian Federation } \\
\text { Southern Federal District } \\
\text { Volgograd region }\end{array}$ & $\begin{array}{l}9,5 \\
7,5 \\
8,4\end{array}$ & $\begin{array}{c}10,4 \\
6,5 \\
7,9\end{array}$ & $\begin{array}{c}10,3 \\
7,4 \\
7,1\end{array}$ & $\begin{array}{c}10,1 \\
7,2 \\
8,1\end{array}$ & $\begin{array}{l}9,9 \\
7,7 \\
6,3\end{array}$ & $\begin{array}{l}9,3 \\
7,6 \\
6,3\end{array}$ & $\begin{array}{l}8,4 \\
7,1 \\
4,9\end{array}$ \\
\hline $\begin{array}{c}\text { Share of organizations making } \\
\text { technological innovations in the } \\
\text { total number of the analyzed } \\
\text { organizations *, } \\
\% \\
\text { Russian Federation } \\
\text { Southern Federal District } \\
\text { Volgograd region }\end{array}$ & $\begin{array}{l}7,9 \\
6,2 \\
6,9\end{array}$ & $\begin{array}{l}8,9 \\
5,3 \\
6,3\end{array}$ & $\begin{array}{l}9,1 \\
6,3 \\
6,0\end{array}$ & $\begin{array}{l}8,9 \\
6,2 \\
7,3\end{array}$ & $\begin{array}{l}8,8 \\
6,6 \\
5,5\end{array}$ & $\begin{array}{l}8,3 \\
6,7 \\
5,9\end{array}$ & $\begin{array}{l}7,3 \\
6,2 \\
4,6\end{array}$ \\
\hline
\end{tabular}

a. On the basis of the year report of the federal statistical survey № 4-innovation «Information about the innovative activity of an organization». Starting from the report for 2011 the organizations with the codification 73 OKVED are included. Beginning with the report for year 2015 the organizations with codification 45.21.7; 45.22; 45.25 OKVED are included. Beginning with the report for year 2016 the organizations with codifications $01.1 ; 01.2 ; 01.3 ; 01.4$. OKVED are included.

In the Volgograd region during recent years the infrastructure for support of the small and medium sized enterprises was created. However in reality the activity of many institutions declared to be the objects of innovative infrastructure is not aimed at the support of innovative enterprises. Thus for instance the activity of the largest part of the enterprises located in the territory of business incubator is not connected with innovations. «Regional guarantee fund» gives support to all enterprises and there are no special preferential terms for innovative companies [3].

The qualitative assessment of the efficiency of measures of the government support of small and medium sized enterprises and state encouragement of the innovative activity of business showed that all the analyzed measures are characterized as conditionally efficient but at the same time having the tendency for efficient tools of government encouragement.

In order to find the place for innovative vouchers in the arsenal of the tools which are already used for support of innovative small and medium sized enterprises and the borders of their use the available tools, their advantages and disadvantages were studied. They partially intercross with innovative vouchers (consulting and expert services provided by the Center for Engineering of Volgograd region, government scientific grants of Volgograd region, grants of the «Fund for support of the development of small enterprises in the scientific and technical sphere» (Table 2). The analysis of the mentioned tools allows drawing the conclusion about the necessity of the introduction of innovative vouchers in the Volgograd region. The innovative vouchers are expected to finance the services in the development of technological innovations, to contribute to the communication between small and medium sized enterprises and scientific and research institutes of the Volgograd regions and to the commercialization of R\&D. Other tools under analysis will add to innovation vouchers in a harmonious way.

The study of the foreign experience of the introduction of innovative vouchers and also the attempts of their introduction in the Tomskaya region allowed developing two models of the innovative vouchers use: classical voucher model with the issuing of an innovative certificate and grant model. At the grant model of the introduction of innovative vouchers the grants in the contest "Innovative voucher" are given by the Committee for Economic Policy and Development of the Administration of the Volgograd region. The authors suggested two variants of the implementation of the grant model: 1) grants are distributed to small and medium sized businesses; 2) grant are given to the organizations of the region having the scientific and research activity (universities, vocational schools, scientific and research institutes, innovatively active enterprises having their own construction and technological services and so on) which have the necessary material and technical resources, well trained personnel which in their turn provide services to small and mediums sized business on a competitive basis. The advantage of the grant model is the opportunity of the attraction of budgetary funds from the federal budget of the Russian Federation under the condition of co financing before the corrections in the legislation of Russia which are connected with the supplementation of financial provision of state support of innovations by means of such form like innovative voucher are made. 
TABLE II. ADVANTAGES AND DISADVANTAGES OF THE TOOLS PARTICALLY INTERCROSSING WITH INNOVATIVE VOUCHERS

\begin{tabular}{|c|c|c|c|}
\hline & Advantages & Disadvantages & Conclusion \\
\hline $\begin{array}{l}\text { Services } \\
\text { of the } \\
\text { Center } \\
\text { for } \\
\text { Engineeri } \\
\text { ng of the } \\
\text { Volgogra } \\
\text { d region }\end{array}$ & $\begin{array}{l}\text { Opportunity to get for } \\
\text { free (at first } \\
\text { application) or under } \\
\text { the condition of co } \\
\text { financing (at } \\
\text { secondary } \\
\text { application) the actual } \\
\text { services in the } \\
\text { development of } \\
\text { investment projects, } \\
\text { in organization of } \\
\text { technological, } \\
\text { financial and } \\
\text { managerial audit, in } \\
\text { making business } \\
\text { plans, in provision of } \\
\text { marketing services } \\
\text { and so on. }\end{array}$ & $\begin{array}{l}\text { The largest part of } \\
\text { services are } \\
\text { standard, they are } \\
\text { not directly related } \\
\text { with innovations, } \\
\text { are made mainly by } \\
\text { private companies } \\
\text { or sole proprietors } \\
\text { presented in the } \\
\text { market. The } \\
\text { receiver does not } \\
\text { have the right of } \\
\text { the choice of the } \\
\text { supplier. Low cost } \\
\text { of services. }\end{array}$ & $\begin{array}{l}\text { Innovative vouchers } \\
\text { are usually used in a } \\
\text { narrow sense as the } \\
\text { definition of } \\
\text { technological } \\
\text { innovations, } \\
\text { contribute to the } \\
\text { establishment of } \\
\text { relations between } \\
\text { universities, } \\
\text { scientific and } \\
\text { research institutes } \\
\text { and small and } \\
\text { medium sized } \\
\text { enterprises and to the } \\
\text { reduction of the gap } \\
\text { between the science } \\
\text { and business. Both } \\
\text { tools are } \\
\text { indispensable and } \\
\text { will supplement each } \\
\text { other. }\end{array}$ \\
\hline $\begin{array}{l}\text { State } \\
\text { scientific } \\
\text { grants of } \\
\text { the } \\
\text { Volgogra } \\
\text { d region }\end{array}$ & $\begin{array}{l}\text { Directions of the } \\
\text { spending of the grant } \\
\text { allow financing at } \\
\text { itsexpense the } \\
\text { services of the } \\
\text { scientific and research } \\
\text { organization } \\
\text { connected with the } \\
\text { development of a new } \\
\text { product, improvement } \\
\text { of technology of the } \\
\text { production process } \\
\text { and the choice of the } \\
\text { providers of services } \\
\text { can be supported by } \\
\text { grant receiver. }\end{array}$ & $\begin{array}{l}\text { The application is } \\
\text { counted on rather } \\
\text { scientific } \\
\text { researcher, its } \\
\text { filling is } \\
\text { complicated for } \\
\text { SMEs. A small } \\
\text { number of grants } \\
\text { (10 grants per year) } \\
\text { at a high } \\
\text { competition with } \\
\text { universities leads to } \\
\text { the situation when } \\
\text { SMEs get no more } \\
\text { than } 1 \text { or } 2 \text { grants. }\end{array}$ & $\begin{array}{l}\text { The mentioned tool } \\
\text { encourages the } \\
\text { providers of } \\
\text { scientific and } \\
\text { research services. } \\
\text { Both of the tools are } \\
\text { indispensable and } \\
\text { will supplement each } \\
\text { other. }\end{array}$ \\
\hline $\begin{array}{l}\text { Grants of } \\
\text { the fund } \\
\text { «Fund for } \\
\text { the } \\
\text { assistance } \\
\text { of the } \\
\text { developm } \\
\text { ent of } \\
\text { small } \\
\text { enterprise } \\
\text { s in } \\
\text { scientific } \\
\text { and } \\
\text { technical } \\
\text { sphere» }\end{array}$ & $\begin{array}{l}\text { Considerable } \\
\text { maximal number of } \\
\text { grants }\end{array}$ & $\begin{array}{l}\text { Programs are } \\
\text { directed only on the } \\
\text { small but not on } \\
\text { medium sized } \\
\text { business. High } \\
\text { competition with } \\
\text { the applicant from } \\
\text { other regions of } \\
\text { Russia which } \\
\text { advance Volgograd } \\
\text { region upon the } \\
\text { innovative } \\
\text { entrepreneurship. } \\
\text { No alternatives to } \\
\text { small innovative } \\
\text { voucher. }\end{array}$ & $\begin{array}{l}\text { In case if a small } \\
\text { enterprise needs to } \\
\text { correct the } \\
\text { production } \\
\text { technology, to solve } \\
\text { specific technical } \\
\text { problem, a small } \\
\text { innovative voucher } \\
\text { would become the } \\
\text { best alternative to the } \\
\text { contests of the Fund } \\
\text { for the development } \\
\text { of small firms in the } \\
\text { scientific and } \\
\text { technological sphere } \\
\text { directed on the } \\
\text { development and } \\
\text { production of new } \\
\text { production. }\end{array}$ \\
\hline
\end{tabular}

The list of services financed by innovative vouchers the following services should be included:

- $\quad$ services in the development and the improvement of products and technologies including the support of design documents, current and technological papers, industrial design;

- $\quad$ services in prototyping, construction of engineering samples and parties, creation of engineering samples of technological equipment, industrial components, minor components, fitting of industrial equipment;

- $\quad$ innovative and technological auditing;

- $\quad$ services in the development of a new business model;

- $\quad$ patenting and patent services.

The data base of the services providers which includes the state and non governmental licensed higher education institutes implementing the scientific research and development, scientific institutes of the Volgograd region. The services can be provided also by innovative active enterprises having own construction and technological departments. When choosing the contractor the following criteria should be used: compliance with the industrial specificity of an organization, university or the sphere of the scientific and research institute in the project; experience of the implementation of a similar project; organizational potential; staff with necessary professional knowledge and qualification; absence of conflicts of interests with the organizers of the competition and of the organization applicant with relatives or legal relations.

It is indispensable of making the issues of innovative vouchers of two types:

- small innovative vouchers with the cost no more than 500000 rubles (without the cofinancing from the part of the applicant);

- big innovative voucher with the cost no more than 2 million rubles (with cofinancing of the applicant not least than $20 \%$ from the cost of the service)

The nominal of the innovative voucher for a specific company winner of the contest (in case of the application of the grant scheme or the sum of the grant) is set by the organizer of the contest coming from the cost of the project, from its social and economic importance and other criteria and also from the amount of money available for the organizer of the project. At the classical voucher model the winners of the contest get a personalized certificate for $R \& D$ and development engineering works (innovative vouchers) with the nominal mentioning.

The main criteria of the project evaluation by the expert commission are: novelty, innovations, patentability of final product, its scientific and technological level in comparison with available analogues in the market; importance of the need satisfied by the new product, purpose of the product, its consumer properties, technical feasibility of the project; prospect of commercialization of final product, availability of economic and social effects from the realization of the project.

The list of the documents attached to the application are: application of the participant in the contest according to the form set by the organizer; client details form; copies of charter documents; report of financial results of an enterprise for the previous year (for legal entities) or tax declaration for the previous year (for sole proprietorships); preliminary requirement list for needed assistance; business plan of the product use where the results of project would be used which 
contains the description of economic, social effect from the implementation of the project (20 pages maximum).

For the assessment of the efficiency of innovative vouchers short term (during one year if a small innovative voucher is given) and long term (during three years) the control over the organizations which implement the project with the help of innovative voucher should be used. This process is needed for the analysis of the further realization of the project, for the evaluation of its social and economic effect and also a further cooperation with small and medium sized enterprises and scientific and research organizations. It is possible also to use the method of control group (comparison of organizations applicants who won the innovative voucher and organizations which were refused, possibility of the implementation of the projects by own forces).

Protection from the risks is presented by the completion of the criteria of the participation in the provision of scientific and research services financed by the innovative voucher of the organization contractor and by the applicants. The protection is also reached by the opportunity of the exclusion form the list of the organizations which provided services in an inappropriate way, by the control of conflict of interest, relative and legal relations at the selection of innovative vouchers receivers, by the monitoring of the achievement of the indices of social and economic effects, opportunity of a partial or complete reimbursement of the money when the declared results were not achieved or when the results considerably deviate from the declared results. The money is paid back only if such failure was not the result of force majeure. When we speak about a considerable deviation from the achievement of the indices of social and economic effect we mean the one that makes up 30\% from the planned values.

The authors have developed the project of the Strategy of encouragement of small and medium sized innovative entrepreneurship in the Volgograd region with the help of innovative vouchers for 2018-2023. The main goal of the Strategy is the encouragement of the innovative activity of SMEs in the Volgograd region by means of the support of their cooperation with government and private suppliers of scientific and research services for the development or improvement of products or processes or for the increase of the labour productivity and profitability of the business. The cooperation between SMEs and scientific organizations can become the basis for further innovations and also for the creation of the clusters, technological parks and innovation nets. This all in its turn will contribute to the creation of a new class of technological entrepreneurs in the Volgograd region.

The implementation of the Strategy is planned for two stages. at the first stage (2018) the goal of the preparation for the launch of the state program of the encouragement of the innovative activity of SMEs by means of the issuing of innovative voucher in the Volgograd region. This stage includes the adoption of the Law of the Volgograd region "About the innovative voucher", development of the state program of the encouragement of the innovative activity of SMEs by means of the issuing of innovative vouchers in the Volgograd region, approval of the list of organizations having the right for the services provision within the program of the realization of innovative vouchers in the Volgograd region, adoption of the regulations about the contest "Innovative voucher", selection of the application form and the methodology of evaluation and filling of applications for the participation in the contest "Innovative voucher"; informing of participants about the start of the contest "Innovative voucher".

The second stage (2019-2023) includes the issuing in the Volgograd region of innovative vouchers, their distribution to SMEs on a competitive basis; monitoring of the efficiency of the projects supported by innovative vouchers; analysis of opportunities of the money use from the federal budget for the co financing of the state program of encouragement of innovative activity of SMEs by means of the issuing of innovative vouchers in the Volgograd region; development of the way of encouragement of innovative activity of SMEs who used the innovative voucher and their cooperation with scientific and research institutes.

The key indices of the strategy are: the growth of the share of SMEs making technological innovations in the total number of SMEs up to 10\%; growth of the share of innovative goods, works and services in the volume of shipped good, works and services of SMEs up to $6 \%$; increase of the share of the expenses for technological innovations in the total volume of the shipped goods of the own production, produced goods and services by own forces up to $2,5 \%$; growth of the share of funds obtained from $\mathrm{R} \& \mathrm{D}$ and research and technical development up to $20 \%$ in revenues of higher institutions of the Volgograd region; increase of number of issued patents for inventions and utility models up to 550 items per year.

The plan of measures includes the following measures: 1) adoption of the Law of the Volgograd region "About the innovative voucher"; 2) development of the state program of the encouragement of innovative activity of SMEs by means of the issuing of innovative vouchers in the Volgograd region; 3) approval of the list of organizations having the right of providing services within the scheme; 4) distribution of innovative vouchers in the Volgograd region; 5) approval of the regulations about the contest "Innovative voucher", application form and evaluation methodology, presentation of applications for the participation in the contest "Innovative voucher"; 6) informing of SMEs about the beginning of the contest; 7) analysis of the applications for the contest, presentation of winners, conclusion of contracts; 8) implementation of projects; 9) analysis of reports in the project; 10) assessment of efficiency of the implemented projects; 11) finding the opportunities of the attraction of funds from the federal budget for the co financing of state program of encouragement of innovative activity of SMEs by means of the distribution of innovative vouchers in Volgograd region; 12) finding the ways of encouragement of innovative activity of SMEs making use of the innovative voucher and their cooperation with scientific and research organizations.

The financial resources within the mentioned strategy will be needed for the following events:

- information booklets for SMEs about the program of innovative vouchers, their distribution among the SMEs and via the banking organizations; 
- issuing of innovative voucher certificates;

- payment of scientific and research services provided to SMEs in the contest "Innovative voucher";

- expenses for contest organization, salaries of the commission members.

The volume of money given for the payment of scientific and research services provided by SMEs in the contest "Innovative voucher" in 2019 amounted to 10 million rubles with a gradual growth of this sum by 2023 to 20 million rubles. The volume of money given for the organization of the contest and for the payment of salaries to contest commission members makes up 100000 rubles.

The authors suggest the use for the cooperation of SMEs and scientific and research institutions of the following tools: creation of innovative nets by means of the selection of the enterprises ready to cooperate into the innovative net on the competition basis and providing them support from the regional budget; cooperation between higher education institutions in the forms of consulting, internship for students, involvement of students into applied scientific research for the contracts implementation; creation of open patent reviews and so on.

\section{CONCLUSION}

The introduction of innovative vouchers by means of the implementation of the Strategy suggested by the authors will contribute to the commercialization of the research and development of scientific institutions of the region and to the growth of the innovative activity of small and medium sized enterprises. In the future on the basis of the actvization of innovative activity of small and medium sized enterprises and of the involvement of scientific and research organizations into the applied research with the help of innovative voucher, the creation of industrial cluster and then on their base of innovative territorial clusters will take place. It is also useful to create large scale industrial enterprises, to take measures in the involvement of the youth into the innovative activity.

\section{Acknowledgment}

The research was financially supported by the Russian Fund for Fundamental Research and by the Administration of the Volgograd region within the scientific and research project «Innovative voucher as a tool of the development of innovative entrepreneurship in the Volgograd region» (project № 16-12-34007).

\section{References}

[1] Parfenova M.V. Development of the state form of stimulation of innovative activity in Russia [Razvitie gosudarstvennoi formy stimulirovaniya innovatsionnoi deyatel'nosti $\mathrm{v}$ Rossii] : PhD thesis. Volgograd, 2013. P. 127-132.

[2] Compiled by the authors on: Science and innovation [Nauka i innovatsii]/ Rosstat. URL: http://www.gks.ru/wps/wcm/connect/rosstat_main/rosstat/ en / statistics / science_and_innovations / science / \#.

[3] Chekalkina A.A. Priority instruments for financial support of innovative activities of organizations [Prioritetnye instrumenty finansovoi podderzhki innovatsionnoi deyatel'nosti organizatsii] : PhD thesis. Volgograd, 2015. P. 97. 